\title{
Brunei Darussalam in 2016
}

\author{
The Sultan Is Not Amused
}

\begin{abstract}
Brunei continued in 2016 to suffer from declining oil and gas prices. The budget deficit grew. The Sultan made economic diversification and "prudent spending" the year's central political themes. He criticized several government institutions during "surprise visits" and sharply attacked the Ministry of Religious Affairs for "delaying" the full enforcement of an Islamic legal reform.
\end{abstract}

KEYWORDS: Brunei, oil price crisis, economic diversification, legal reforms, Sharia

Brunei Darussalam is governed by a monarch holding absolute executive and legislative powers. Sultan Hassanal Bolkiah is Prime Minister, Minister of Finance, Defense, Foreign Affairs, and Trade, commander of the army and police, and Head of Islam. Brunei remains the only ASEAN country without general elections, an organized opposition, or an independent civil society. Since achieving full independence from the British in I984, this centralization of powers has never affected the Sultan's popularity. Although his rule is authoritarian, it is not a dictatorship - the government strongly emphasizes the rule of law, and unlike in earlier decades, there are no political prisoners. ${ }^{1}$

To be sure, public discourse is tightly controlled: Brunei is ranked I55th of I80 countries in the Press Freedom Index 2016, and technically a state of emergency has been continued since a short-lived rebellion in I962. However, Brunei's oil-funded welfare state has brought about an exceptional degree of

Dominik M. Müller is Head of the Research Group "The Bureaucratization of Islam and its Socio-legal Dimensions in Southeast Asia" (DFG Emmy Noether Program) at the Max Planck Institute for Social Anthropology, Halle, Germany. Email: <muellerdo@eth.mpg.de>.

I. United States Department of State, Bureau of Democracy, Human Rights and Labor, Brunei 20I5 Human Rights Report. 5, at <http://www.state.gov/documents/organization/25296I.pdf>, accessed [accessed December I, 2016].

Asian Survey, Vol. 57, Number I, pp. 199-205. ISSN 0004-4687, electronic ISSN 1533-838X. ( 2017 by The Regents of the University of California. All rights reserved. Please direct all requests for permission to photocopy or reproduce article content through the University of California Press's Reprints and Permissions web page, http://www.ucpress.edu/journals.php?p=reprints. DOI: https://doi.org/Io.I525/ AS.2017.57.I.199. 
social security and stability, making Brunei the highest-ranking Muslimmajority country in the UN Human Development Index. Citizens enjoy subsidized housing, free health care and education, and do not pay personal income tax. One-quarter of the working population, and a much larger percentage among the ethnic Malay majority population, is employed by the government. Malays are privileged under the state ideology of Melayu Islam Beraja (Malay Islamic Monarchy), which makes Malayness a core element of prescribed national identity.

Oil and gas-related revenues constitute over 9o\% of exports. Declining oil prices, from US\$ IIo per barrel in July 2014 to less than US\$ 40 in January 2016 and US\$ 49 in October, with a parallel decline of liquefied natural gas (LNG) prices, caused growing budget deficits. The budget for the fiscal year 20I6-I7 (ending on March 3I, 20I7) is Brunei Dollars (BND) 5.6 billion (US\$ 3.98 billion), a slight reduction from BND 5.7 billion (US\$ 4.05 billion) in 20I5-I6. The projected public revenues decreased to BND I.76 billion (US\$ I.25 billion) and the fiscal deficit grew from BND 2.28 billion (US\$ I.62 billion) in $2015-16$ to BND 3.84 billion (US\$ 2.73 billion) in 2016-I7, which illustrates a worsening trend. The budgets of all ministries, excluding defense (which already saw a cut of $25 \%$ in 2015-16), were reduced for 2016-I7. Total government spending will be cut by $\mathbf{1 2 . 5} \%$.

The government did not reduce salaries of existing positions in the public service sector. Its oil and electricity subsidies, US\$ 900 per person (latest data: 20I4), remain untouched, but public welfare spending, including health care and national housing, will be reduced in 2016-17. In the third quarter of 2016, GDP at current prices was estimated BND 3.8 billion (US\$ 2.6 billion), a decline from BND 4.7 billion (US\$ 3.3 billion) vis-à-vis the first quarter of 20I5. GDP at constant prices in the third quarter of 2016 declined $3.8 \%$ in year-to-year comparison. The oil and gas sector declined by $3.8 \%$, whereas the non-oil and gas sector decreased by $3.7 \%$.

Despite these data, the Asian Development Bank (ADB) expects the overall Brunei economy to grow at $\mathrm{I} \%$ in 2016 due to expanding oil production and LNG manufacturing. The International Monetary Fund, in contrast, expects a decline by $2 \%$, but predicts $3 \%$ growth for 2017 . The ADB similarly estimates that with recovering oil prices, $2.5 \%$ growth could be reached. Important contributions also come from the construction sector. They include infrastructure projects, among them three new bridges, one crossing over $30 \mathrm{~km}$ of water between Brunei-Muara and Temburong District, an exclave separated on land 
by only a few kilometers of Malaysian territory. Also planned is a large integrated oil refinery and petrochemical complex in Pulau Muara Besar. Another sector, agriculture, witnessed substantial growth, as did sales for chemicals and machinery and transport equipment. The majority of exports go to Japan (43\%, including $90 \%$ of Brunei's LNG exports), followed by Thailand and India. Most imports come from Malaysia, the US, Singapore and China.

The Sultan and his ministers frequently stressed the urgency to reduce Brunei's overdependence on oil and gas exports. His speech marking the New Year 2016 set the tone by making economic reforms and "prudent spending" its central themes. He announced new initiatives, such as a Foreign Direct Investment and Downstream Industry Committee working on economic reforms to attract foreign investors, and a Business Support Centre providing assistance for small and medium enterprises (SMEs). The Sultan also unveiled plans for a BND 300 million (US\$2 23 million) infrastructure project, a high-voltage electricity transmission line to improve domestic electricity supply and resource efficiency. He stressed growth potentials in agriculture, fisheries, and manufacturing, as well as in financial, transportation, logistics, and telecommunications services. He urged private and stateowned companies to export products.

The government organized an "Enterprise Open Day" on March 25, a knowledge-sharing platform for entrepreneurs, professionals, financial institutions and state authorities. SMEs were invited to submit problems they face to receive advice, while simultaneously learning about the experiences of others. A total of $4 \mathrm{I} 5$ attendees from 449 enterprises participated in the threeday-event. As a follow-up, the government created an online portal and a Business Helpdesk where enterprises can request specialized assistance. Another initiative, DARUSSALAM Enterprise (DARe), is a statutory body that supports start-up and expanding enterprises to build capacities and achieve access to local and international markets.

The government made substantial efforts to create a more attractive, efficient and predictable legal framework for foreign investors and local entrepreneurship. In 2016, Brunei moved in the World Bank's "ease of doing business" score from I05th (2015) to 84th (2016), as the year's most improved economy. Corporate tax has been reduced to $18.5 \%$, and a new law, Insolvency Order 2016, has been enacted. The Order consolidates existing provisions to insolvency (under the Companies Act) and aims to place greater emphasis on rescuing and rehabilitating companies that are facing difficulties 
as well as protecting creditors and debtors. Some of its provisions have been adopted from similar legislation in Singapore and the UK. The law only applies to corporate insolvency (individual insolvency is regulated under the Bankruptcy Act). A Small Claims Tribunal will be established in three of four districts to facilitate cases, with jurisdiction for claims up to BND Iо,оoо (US\$ 7,IOI) related to the sale of goods and services, and damaged properties. The Supreme Court plans to form a Commercial Court responsible for disputes over contracts, exports and imports, (re)-insurance, banking and financial services, and commodity purchases, for claims of up to BND 300,000 (US\$213,038). The president of the Brunei Law Society repeatedly stressed that further measures are needed to make foreign investors feel adequately protected.

During and after several "surprise visits", the 70-year-old Sultan criticized ministries and state institutions in an exceptionally outspoken manner. In the absence of oppositional voices, he appears to play this role himself now. In 20I5, he had used one of his regular, normally much more friendly "surprise visits" to sharply attack the police over corruption cases. In 2016, his targets included the Ministry of Religious Affairs (MoRA), Ministry of Foreign Affairs and Trade, Ministry of Health, Ministry of Home Affairs, the capital's Municipal Department, and a hospital. I will only describe the MoRA case here.

\section{SHARIA REFORM}

In 20I4, Brunei enforced the Syariah [Sharia] Penal Code Order 2013 (SPCO), a legal reform in preparation since the 1990s that bolsters Sharia law, when applicable, to the detriment of British-derived laws, a colonial legacy. Since the colonial period, Brunei's legal landscape has consisted of a dual system comprising separately coexisting Islamic and "civil" laws and courts. With the SPCO's introduction, for the first time some of Brunei's Islamic legal provisions now also apply to non-Muslims. Internationally much discussed, the Order includes punishments up to death by stoning, the amputation of limbs, and lengthy jail terms as maximum penalties. Its many other provisions include strict procedural conditions, a high burden of proof on the prosecution, and in some sections, options to free the accused through repentance.

The reform will be enforced in three stages: The first began in May 2014. Most provisions, including the harshest punishments, will be enforced in 
later stages. The second phase starts I2 months after an additional code regulating procedural aspects (including investigation/prosecution) called Syariah Courts Criminal Procedure Code (CPC), has been presented. The third begins 24 months after that. In 2014 and in 20I5, the former Minister of Religious Affairs described the CPC as nearly ready, but did not present it. Poorly informed international observers began to speculate about whether the Sultan might have abandoned the Order due to assumed international pressure.

The Sultan unambiguously rejected such claims from the beginning in his royal address on May I, 20I4 declaring the SPCO's enforcement, but noted in the same speech that "full responsibility" for implementing the new law "with trust and courtesy" was now with the "relevant agencies," including the MoRA (while its minister stood next to him on stage). Related or not, the same minister was replaced in late 2015 without explanation. Shortly afterward, in February 20I6, the Sultan openly confronted the Ministry as part of a surprise visit, saying he "refused to listen to excuses" and insisting that officials "explain the two-year delay" in finalizing the CPC and thus starting the SPCO's second phase. ${ }^{2}$ He asked how many provisions had been enforced and even mimicked possible excuses: the Ministry might point to the Attorney General's Chambers (AGC), tasked with vetting the Ministry's draft, and vice-versa. The Sultan added: "How thick is the draft? The AGC might tell us there are many other legal documents that need to be urgently dealt with too," which he called an "unacceptable excuse": "Where is the Minister of Religious Affairs? And where is the Attorney General? Why have they not come forward to remedy this unsatisfactory situation?" Bureaucratic inaction, he warned, might make the SPCO_legislated "solely for the sake of Allah, not in pursuit of glamour"_- "look worthless."

The attack continued: "The minister and his deputy minister... should not simply enjoy making visits upon visits ... to schools, mosques and elsewhere.... (B)oth of them pay a visit to the same place and enjoy media coverage," but "if the events are becoming too many ... what about office work and worse, if too many attend them - the minister, his deputy minister and a horde of other officers! Is it not more reasonable for one of them to make the visit while the other stays behind?" The Sultan also criticized 2016.

2. Quoted in "HM questions delay of Syariah law enforcement," Brunei Times, February 27, 
"weaknesses" in Islamic propagation, the education system, and poor Arabic proficiency among students.

MoRA Minister Badaruddin Othman responded that the "already completed" CPC would be presented in June 2016 (by early January 2017 this had not occurred), so that phase two could start I2 months later. "Final changes" were made to make the SPCO "as fair as possible and carried out according to Islamic law requirements." As predicted by the Sultan, he pointed to repeated reviews by the AGC and the Ministry, as the CPC would involve complex challenges such as training investigators, courts, and those who conduct "punishments such as amputation of limbs."3 Meetings were reportedly held every day. Apparently, the Islamic bureaucracy had initially underestimated the practical challenges involved in its long-awaited ideological prestige project. The MoRA's budget for 20I6/7 includes SPCO-assigned funds. In the 2015/6 fiscal year, 247 crimes were prosecuted under existing Sharia laws.

Brunei's Islamic University (UNISSA), established in 2007, has produced a first group of graduates holding double degrees as Bachelor of Laws and Bachelor of Shariah Law. The Sultan declared that UNISSA graduates from all disciplines should become a "driving force" in the SPCO's implementation, and "support government administration." Around $40 \%$ of UNISSA students who graduated between $201 \mathrm{I}$ and 2014 are unemployed. The SPCO may create new job opportunities.

In August 2016 the Sultan, once again, dissolved his Legislative Council. It provides a platform for announcing/explaining government policies, including budgets, and discussing matters of public interest. He will announce the new members before the next session in 20I7. Beyond economy-related discussions, one controversial issue raised this year, without results, is the situation of the Brunei-born stateless, who are excluded from the welfare state's generosity and face restrictions to travel and to own/purchase land. This group mainly consists of parts of the ethnic Chinese community, many of whom have lived for generations on Bruneian soil, as well as a small number of ethnic Iban and Penan, who do not belong to the seven officially acknowledged "indigenous" ethnicities (puak jati). As Brunei nationality is based on a modified form of jus sanguinis ("right of the blood," as opposed to jus soli, i.e., "right of the soil"),

3. Quoted in "MoRA, AGC finalising Syariah Courts Criminal Procedure Code," Brunei Times, March I5, 2016.

4. Quoted in "Paint accurate picture of Islam," Brunei Times, March I5, 2016. 
descent rather than the place of birth is the decisive category for obtaining citizenship. Under the Brunei Nationality Act of 196I, permanent residents can nevertheless apply for citizenship if they fulfill a list of criteria, but lengthy bureaucratic procedures, as well as a language test requiring high proficiency in standard Malay, which substantially differs from the normally spoken informal Brunei Malay, make it very difficult for many stateless persons to change their status, particularly among the older generation.

As in previous years, the Sultan distributed "personal gifts" (kurnia peribadi) (i.e., money), this time to 17,284 recipients. Citizens traditionally submit letters to ask the "Caring Monarch" for individual support. More than a thousand received keys for new government-subsidized houses, personally presented by the Sultan. Waiting times are, however, sometimes more than Io years. Some "needy" converts to Islam received material support, in singular cases new houses.

Brunei continues to have friendly international relations in all directions and avoids any diplomatic tensions, including the South China Sea dispute. The government continues to avoid making direct public references to the obvious disagreement resulting from its own territorial claim within China's claimed "nine-dash line," and instead emphasizes its "commitment to peace" in the South China Sea. There are unverified reports that China has offered Brunei jointly conducted deep sea explorations and production sharing. Brunei was a founding member of the Trans-Pacific Partnership (TPP) and has expected to benefit greatly, as $64 \%$ of total trade has been with its member states. With the election of Donald Trump as the next US president, who described the TPP as a "disaster" and "horrible deal" during the election campaign, it remains to be seen whether or in which form the project will be continued.

\section{UPDATE}

In November 2016, one of Brunei's three daily newspapers, the Brunei Times, was closed after having existed for Io years in which it sometimes tested the tight boundaries of local press freedom. The official reasons given by the newspaper were "business issues," "challenges from the alternative media," and problems with "reporting and journalistic standards that should meet the mark set." The paper expressed gratitude to the government "for bearing with us" and for "having continued to extend the licence to publish despite all the issues." More than Ioo staff members lost their jobs. 